\title{
The Issues on Site Surveying during the Construction of a Bridge Span with the Cantilever Method**
}

\section{Introduction}

Construction of new road engineering structures or modernization of the existing ones is not possible without comprehensive site surveying. Technical problems encountered during the implementation of transport investments can pose a challenge for engineers in these cases, among others, where advanced building techniques are applied.

This article presents the implementation process of site surveying during the construction of a bridge structure erected using the cantilever method. An example of surveys carried out during the construction of a bridge across the Wisłoka River in Łabuzie, in the traffic route of the national road No. 4 between Machowa and Łańcut, at 538+256.00 km was used.

The cantilever method applied during the construction of the bridge span required specialized skills and continuous presence of surveyors, as well as their special commitment.

As part of the modernization of the national road No. 4 Jędrzychowice Korczowa, at the section between Machowa and Łańcut, in Łabuzie (the municipality of Pilsen, Podkarpackie Province), the old structure was replaced by a new one, meeting the current technical and traffic requirements. At $538+256.00 \mathrm{~km}$, two symmetrical road bridges of prestressed concrete were designed, to be implemented using the cantilever technique (Fig. 1). The three-span load-bearing structure was situated on a straight section of the road. The structure has a static scheme of a continuous beam. The length of the external spans is $41.5 \mathrm{~m}$ and of the central span $-84.0 \mathrm{~m}$. The box-section span of the height of $4.60 \mathrm{~m}$ to $1.90 \mathrm{~m}$ was made of prestressed concrete. The support was executed on massive concrete abutments with suspended wings.

\footnotetext{
* AGH University of Science and Technology, Faculty of Mining Surveying and Environmental Engineering, Krakow, Poland

** The article was prepared within the scope of the AGH statutory research no. 11.11.150.005
} 


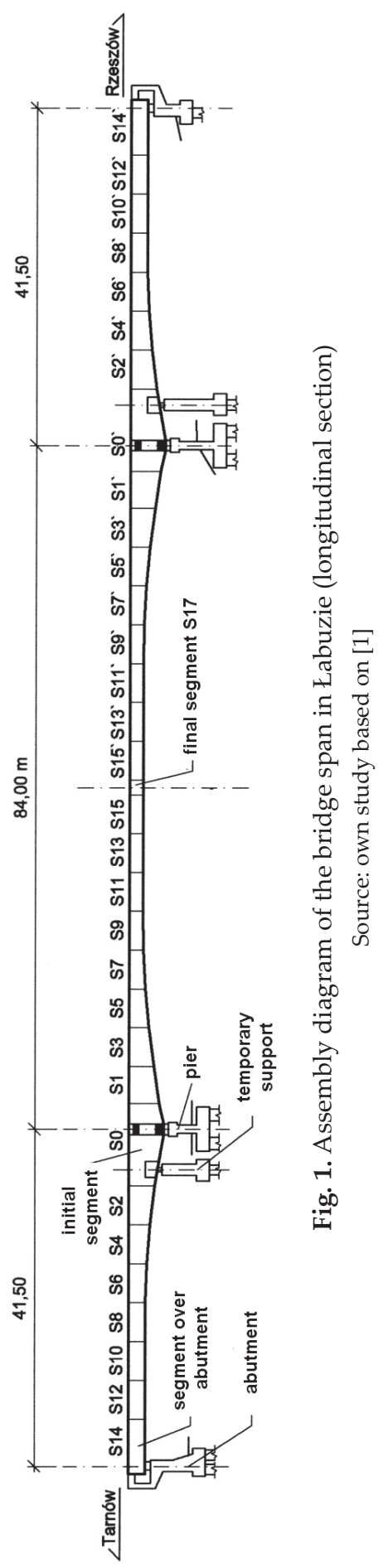


The two intermediate pole-section supports (piers) have cross-sectional dimensions of $1.20 \mathrm{~m} \times 9.00 \mathrm{~m}$ and the height of 3.50 and $5.50 \mathrm{~m}$, and are topped with a pile cap. All the supports of the bridge were erected on piles with large diameters. The total length of the bridge is 187.1 meters and the width is $13.35 \mathrm{~m} \mathrm{[1]}$.

\section{Technical Characteristics of the Cantilever Method}

The cantilever method is characterized by the commencement of construction work with the initial (head) segment located over the pier, then successive segments are added symmetrically or asymmetrically (cf. Fig. 1). Having built the next segment of the span, the form is moved along the axis of the bridge, and then the process is repeated up to the middle segment (the so-called final segment), which links the structure with the one built concurrently on the adjacent pier. The individual segments are executed taking into account the so-called camber (reverse deflection), introduced in order to reduce the target deflection of the span by the fixed and variable loads.

The construction of the span is facilitated by the use of an auxiliary steel girder mounted over the span. Most frequently, its length is about 1.6 spans of the longest the bridge span. The girder enables us to hang the scaffold, to transport materials, equipment and people. In addition, for the spans with a fixed height, for safety reasons, temporary supports and cable stays are used. Another characteristic technical element is a scaffolding trolley. It is a kind of a scaffold which supports the formwork and is used as a working platform. It can be suspended to the steel girder or it moves on the previously created segments. The scaffolding trolley should have high stiffness, be easy to assemble, move and disassemble, as well as to allow us to change the shape of the segment [2].

\section{Specificity of Site Surveying during the Construction of a Span with the Cantilever Method}

\subsection{Introduction}

The process of bridge construction site surveying includes detailed measurements performed within the location survey, setting out measurements and as-built measurements [3, 4]. The points which are necessary for the structure implementation are staked out and verified, based on the coordinates resulting from the project. These measurements are sequentially performed during the construction of foundations, abutments and piers, bearings and the span of a bridge structure.

The range of bridge span construction site surveying depends on the adopted construction method. Each method requires a different approach, the preparation 
of varied data, the use of different stakeout methods, etc. This work presents an example of a prestressed concrete span built using the cantilever technique [5]. The technical problems involved in the application of this method are associated with a complex assembly of the scaffolding trolley together with the span formwork, which must be coordinated by a surveyor.

The most commonly used measurement method during construction site surveying of the bridge in Łabuzie was the free station method. It is especially useful on the construction site, as it allows the location of a position at any spot, which is suitable for measurements. The location of a free station was determined by resection to the geodetic control points. For precision reasons, it is best for the measurements to be performed with at least three points, but to achieve resection, aiming directions for two points are sufficient (each resection should be followed by a control, e.g. based on the points staked out from another position). Having performed the resection, the total station automatically calculates the coordinates of the position and gives their setting out accuracy. As a result, polar method survey is possible. Despite the convenience of using the free station measurement method, during a stakeout it happened that not all the points could be staked in that way. Sometimes, the construction in question required the staking out of points that have not been prepared previously at the office. In such situations, measurement options Projection.Line and Line, available in the total station, also proved to be useful, allowing us to stake out the points of specified offsets and the difference in elevation relative to a particular measurement line defined by two points (e.g. points of the bridge axis).

During the site surveying of bridges erected in the cantilever method, special attention should be paid to the accuracy of the performed work. The basis for achieving satisfactory accuracy is a well designed, measured and aligned geodetic control network, as well as the use of surveying instruments having the required accuracy. In the case of the investment in question, the mean error of the geodetic control point position was $0.0037 \mathrm{~m}$, and the maximum error was $0.0064 \mathrm{~m}$. Detailed horizontal stakeout and as-built surveys were performed with a maximum deviation of $\pm 5 \mathrm{~mm}$, which was possible to achieve using the total station with distance measurement accuracy of $\pm(3+2)$ ppm, and $3 "$ of angle measurement accuracy.

\subsection{Site Surveying of the Initial Segments of the Span}

The construction of a span of a structure in the cantilever method begins over the piers with the so-called initial segments. In the case of the bridge in Łabuzie, the work at the beginning was conducted on the scaffold assembled around the support. After staking out the extreme points of the bottom deck of the initial segment and identifying their ordinates (points H12 and H13 in Figure 2), a systematic control of the formwork assembly was carried out. First, a survey of the lower edge of the formwork was conducted. It is important to compare the measured ordinates with the design ordinates enlarged by the values of cambers. On the formwork of the bottom deck, the locations of the planned openings was marked. 


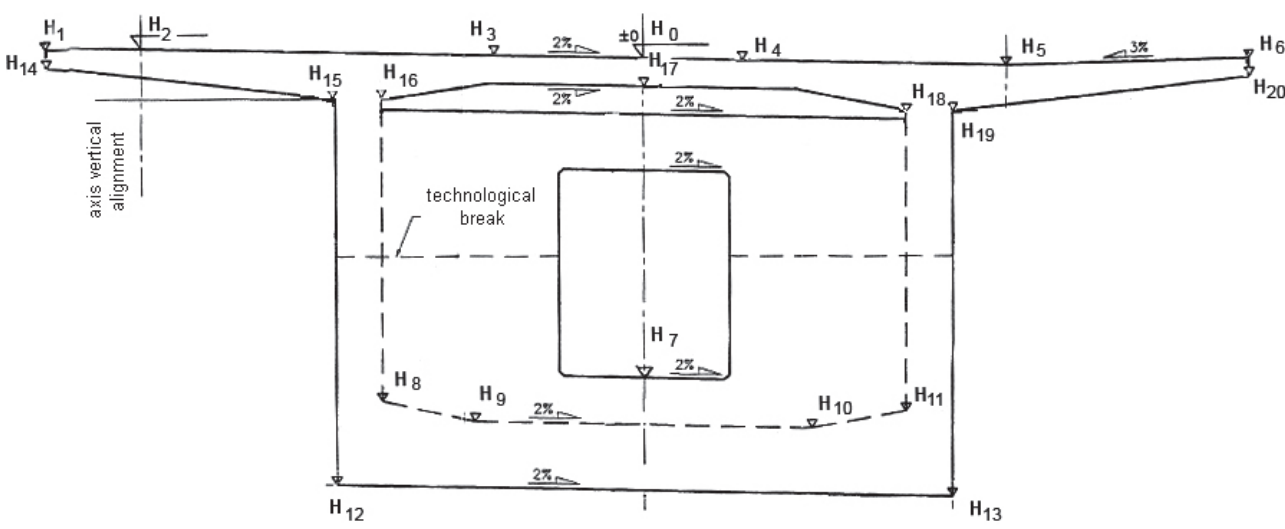

Fig. 2. Cross-sectional sketch of the initial segment of the bridge span in Łabuzie Source: [6]

The next task of the surveyor was to determine ordinates of the points located on the upper surface of the bottom deck of the initial segment (points H7, H8, H9, $\mathrm{H} 10$ and H11 in Figure 2). The elevations were checked at four cross-sections of the segment. After concreting the bottom deck, the ordinates were checked again.

Then, the delineation of the contour of the upper deck formwork of the initial segment was performed. When the formwork was assembled and the reinforcement was placed, re-measurement was carried out. These measurements were performed in two sections located at the contacts of the segment with the adjacent ones. In addition to the control of the elevation (points H1, H2, H3, H4, H5, H6 in Figure 2), the horizontal position of the extreme points was examined. Before concreting the deck, location of the designed openings on the formwork was determined. Also, before concreting, a survey of prestressing tendons tubes was made, based on which sketches have been drawn up. Having verified the correctness of the measured dimensions with the designed ones, it was possible to proceed to concreting. As-built survey was carried out for the completed initial segment.

\subsection{Site Surveying during the Construction of the Segments between the Piers}

During the construction of the bridge in Łabuzie, after the completion of the initial segment, the scaffolding trolley assembly commenced. During the construction of the consecutive segments, site surveying works were similar in each case, as described below.

1) The first step before commencement of staking out the position of scaffold for a new segment was to check horizontal details of the axial point of the previously completed segment, in the part which is to connect with the newly staked one. 
2) Then, the work aimed at positioning the scaffolding trolley was performed (Fig. 3). Since the formwork had to be adjusted to the previously completed segment, the extreme points for the new segment were staked out only from the side on which the next one was to be built.

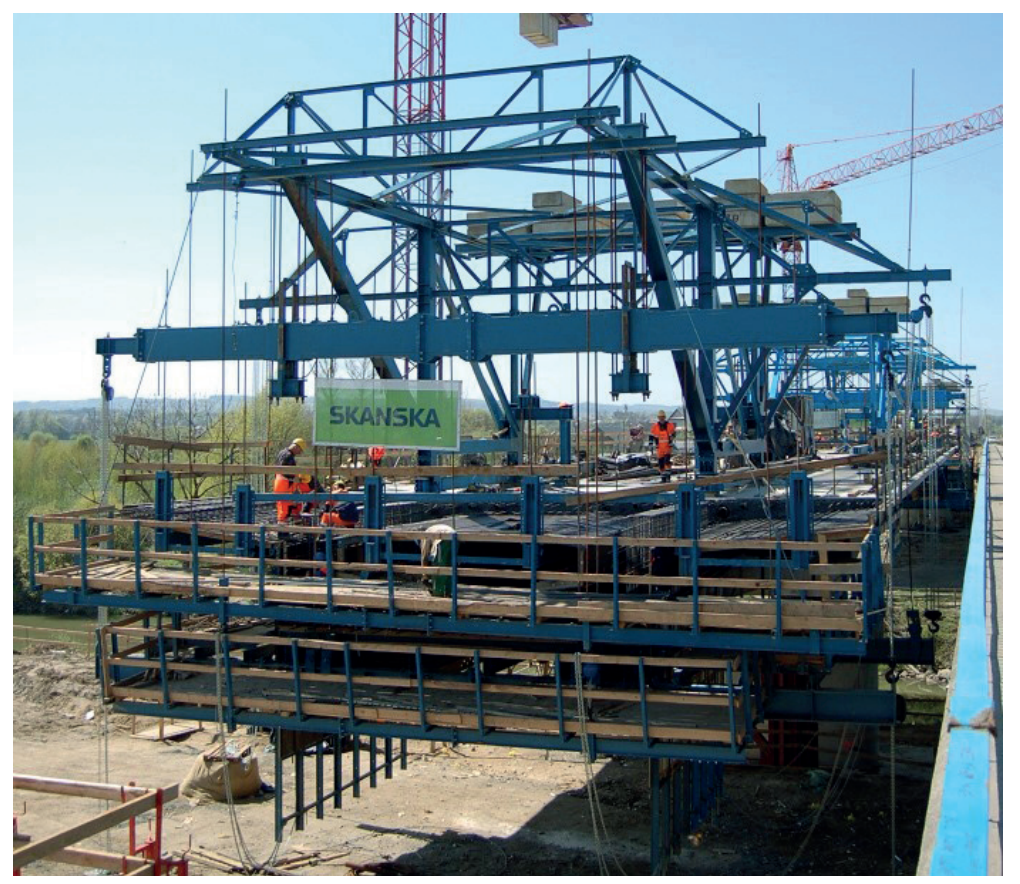

Fig. 3. View of the girder and the scaffolding trolley at the construction site of the bridge in Łabuzie

3) Setting the scaffolding trolley commenced with determining the position of the upper deck scaffold. The points on the edge of the segment were consecutively staked out, or if it was impossible, in accessible places, indicating a reflection from the assumed line of measurement (using the option of the total station: Projection.Line). Having determined detailed position of the points, the measurement of their ordinates was carried out (points H14, H15, H16, H18, H19, H20 in Figure 2). The differences in elevations between the measured ordinate and the designed one were given to assembly workers, who then corrected the position of the scaffold. The differences between the ordinates of individual points were adopted at $\pm 2 \mathrm{~mm}$.

Then, fitting the axis of the upper deck scaffold was made into the designed axis of the bridge. The assistant surveyor held a mirror in the axis of the scaffold, and the surveyor operating the total station set a line defined by two points (using the option: Projection.Line), the first of which was located 
in the axis of the bridge, and the other one on a line perpendicular to the axis. Then, the current measurement values were given to the assembly workers, who moved the whole scaffold by the defined value. The measurement was carried out until a desired position was achieved.

After a detailed setting of the upper deck scaffold, all the points were checked again, and then the extreme points of the formwork and the points located in the axis of the designed openings in the deck were staked out.

4) During the next stage, the position of the bottom deck scaffold was determined. As previously, the position of successive points was established, and their ordinates were determined (points H8 and H11 in Figure 2). Then, the axis of the scaffold was fitted into the designed axis of the bridge, and at the end, the contour of the formwork and the openings in the structure were determined.

5) After placing the reinforcement, a survey of the segment formwork before concreting was carried out. Most attention was paid to maintaining the design ordinates. Because of the designed drainage inclination towards the axis of the effluent, the measurements were performed at eight points. Before concreting, the locations of the prestressing tendons tubes were checked as well.

6) After concreting, an as-built survey of the completed segment was carried out. These measurements included three points located in two sections. The first section from the previously completed segment, and the second from the designed one. The results of the measurements allowed for a comparison of the designed ordinates with the executed ones. In accordance with the requirements relating to the execution of spans of concrete (e.g. [7]), dimensional deviations of the load-bearing structure shall not exceed, for example in the case of a span length of $\pm 2 \mathrm{~cm}$, the theoretical span of $\pm 1 \mathrm{~cm}$, the longitudinal axis in the plan of $\pm 3 \mathrm{~cm}$ and the ordinates of $\pm 1 \mathrm{~cm}$.

As part of the described implementation, in the case of identifying excessive deviations, it was possible to make corrections during the stakeout of consecutive segments. An exemplary sketch from as-built surveys is shown in Figure 4.

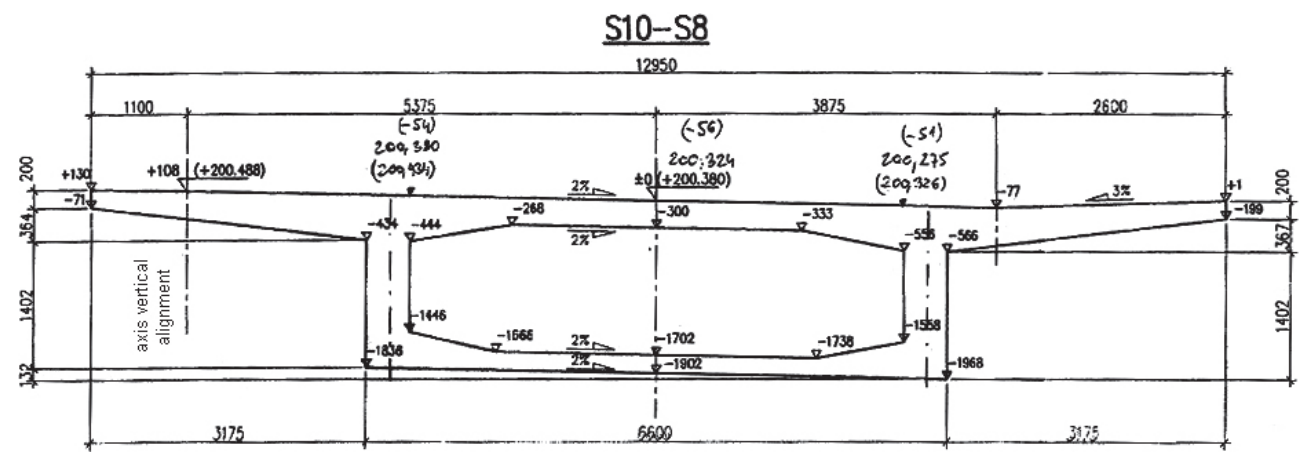

Fig. 4. Sketch from as-built surveys of the segment S10 - section S10-S8

Source: [6] 


\subsection{Site Surveying during the Construction of the Final Segment}

During the implementation of the investment in question, the construction of the span was carried out concurrently over the two piers. Having completed segments S15 and S15' (cf. Fig.1), the implementation of the so-called final segment, labeled S17 commenced.

The formwork of the final segment had to be matched to the existing segments S15 and S15', therefore site surveying before concreting in this case was limited to checking the ordinates of the points at the end of segments S15 and S15', and comparing them with the project. After concreting the final segment, an as-built survey was performed.

\subsection{Site Surveying during the Construction of the Segments over the Abutments}

The segments located over the abutments were executed in an analogous manner to the initial ones. The difference in site surveying resulted only from the adoption of two measurement sections. The as-built survey after concreting was performed in the same manner as for the span segments.

\subsection{As-built Survey of the Span after Target Compression}

The final construction stage of the bridge span in Łabuzie, implemented after all the segments had been completed, was target compression of the structure. After the compression, geodetic surveying of the upper deck of the span was performed. The ordinates of the points located in the axis of the structure, at segment connection points, were checked. In addition, the position of the sewage drains were subject to control, and deviations from the designed position were shown in the sketches using arrows, with their value given.

\subsection{Elevation Control of the Structure}

In order to carry out elevation control of the bridge in accordance with the project [1], four temporary benchmarks were established on the piers from the side of the abutments, and two benchmarks on each temporary support. Similarly, on the upper deck of the span, three benchmarks were established within ten centimeters from the end of each segment. The benchmarks were marked in red on the deck (e.g. Fig. 5). In addition, on the initial segments, benchmarks were established in the axis of the piers and assembly supports.

As part of the elevation control, leveling of the benchmarks located on the piers was performed one hour after each concreting. Leveling of the measurement benchmarks established on the upper deck of the span was carried out after concreting and compression of successive segments, after disassembly of the scaffolding trolleys and ballast, as well as after target compression. 


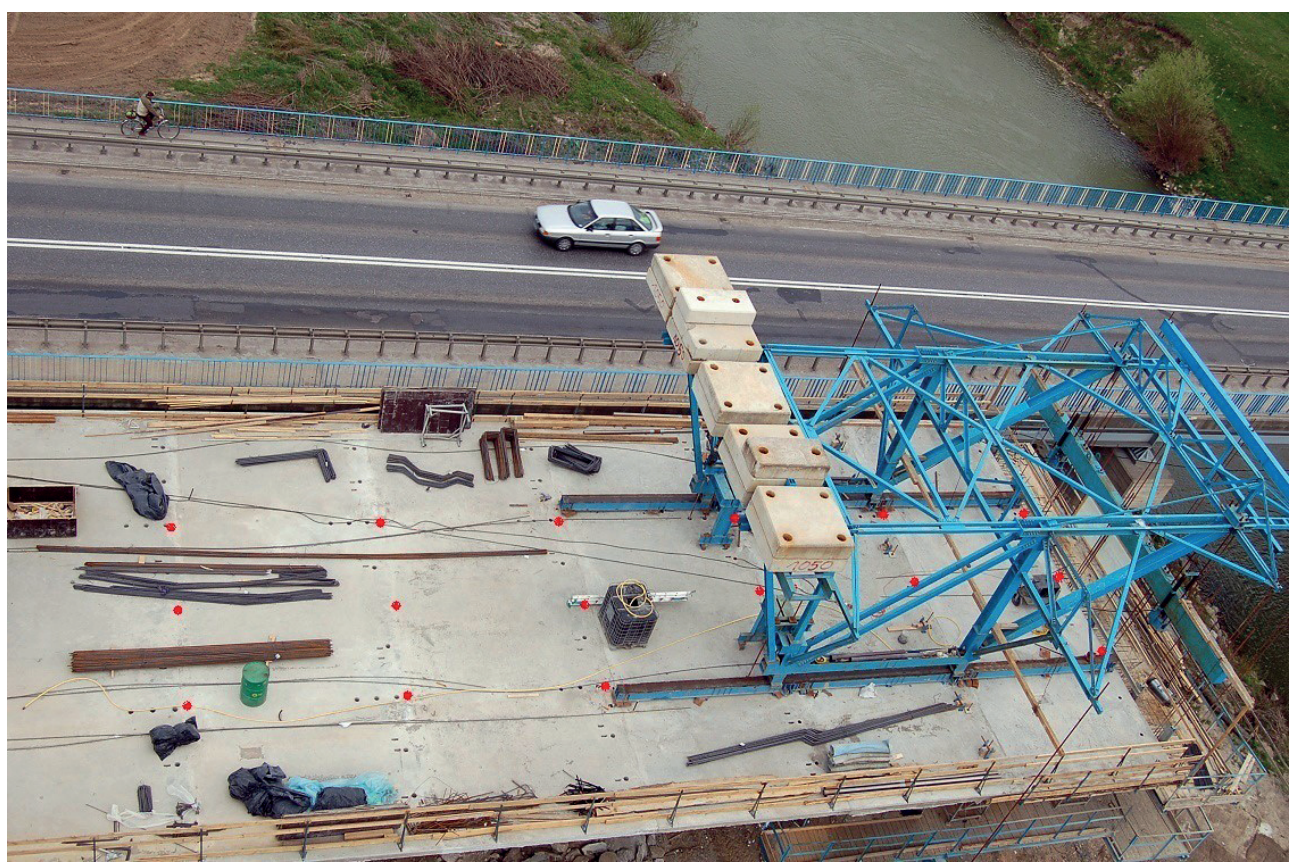

Fig. 5. Exemplary arrangement of temporary benchmarks (points in red) on the span deck of the structure in Łabuzie

The measurements were carried out on each of the axial benchmarks, and during the execution of the segments, at all points of the new segment section, and at the contact with the previous one.

These measurements were carried out in order to control the subsidence of the structure and the deflection of the span during construction. On the basis of the leveling data, in the case of identified subsidence or deflection values different from the assumed ones, the designer had a possibility to make adjustments of the ordinates of the points at the successive implementation stages.

\section{Summary}

The article aimed to present an analysis of surveying methods employed during the construction of a bridge span erected using the cantilever method, exemplified by the experience gained during the construction of a crossing over the Wisłoka River in the traffic route of the national road No. 4 in Łabuzie at $538+256.00 \mathrm{~km}$.

Sometimes, the site surveying performed during the construction of this bridge required creativity during stakeout and as-built surveys. During the preparation stage in the office, the surveyor is not able to foresee all the circumstances which come up in the construction process, therefore, during the surveys, the optional use 
of the methods for fast, yet sufficiently accurate measurement is particularly important. In difficult conditions limiting visibility and accessibility to assistant surveyors, more and more complex software of electronic total stations is of a great help. In this case, the method of free station proved to be the most convenient. Thanks to this method it was possible to perform the measurements from any point on the building site. The experience gained from the construction of the bridge in Łabuzie is a confirmation of the view that only continuous control surveys and constant cooperation between a surveyor, a designer and a building site manager make it possible to successfully complete the project.

\section{References}

[1] Projekt wykonawczy budowy mostu przez rzekę Wisłoka w miejscowości Łabuzie w ciagu DK nr 4 Jędrzychowice-Korczowa, $\mathrm{km} 538+256$ wraz z dojazdami i robotami towarzyszacymi. Skoplak Z., Mazera A. Biuro Projektów i Ekspertyz Budowli Konstrukcyjnych MOSTOPROJEKT, Kraków 2005.

[2] Furtak K.: Wprowadzenie do projektowania mostów. Politechnika Krakowska im. Tadeusza Kościuszki, Kraków 1999.

[3] Gocał J.: Geodezja inżynieryjno-przemysłowa. Cz. 2. Uczelniane Wydawnictwa Naukowo-Dydaktyczne AGH, Kraków 2005.

[4] Przewłocki S.: Geodezja inżynieryjno-drogowa. Wydawnictwo Naukowe PWN, Warszawa 2009.

[5] Skrętkowska A.: Geodezyjna obstuga budowy obiektu mostowego wznoszonego metoda nawisowa na przykładnie mostu w Łabuziu w ciagu drogi krajowej $\mathrm{nr} 4, \mathrm{~km}$ 538+256. AGH, Kraków 2010 [diploma thesis].

[6] Operaty geodezyjne sporzadzone w ramach geodezyjnej obstugi budowy mostu przez rzeke Wisłoka w miejscowości Łabuzie w ciagu DK nr 4 Jędrzychowice-Korczowa, km 538+256. Przedsiębiorstwo Geodezyjne GEOPRZEM, 2008-2009.

[7] Madaj A., Wołowicki W.: Budowa i utrzymanie mostów. Wymagania techniczne, badania, naprawy. Wydawnictwa Komunikacji i Łączności, Warszawa 1995. 